\title{
Chapter 11 \\ Centenarians, Semi-supercentenarians and the Emergence of Supercentenarians in Poland
}

\author{
Waclaw Jan Kroczek
}

\subsection{Introduction}

Before 1795 the Polish-Lithuanian Commonwealth was home to people of several different cultures and languages, and included the territories of the present-day countries of Poland, Lithuania, Latvia, Estonia, Belarus and Ukraine. The partitioning of the Commonwealth in 1795 among the European powers brought about a German Poland, a Russian Poland and an Austrian Poland, each with its own political system, domestic and foreign policy, and official language. Poland did not achieve independence until 1918; hence the centenarians, semisupercentenarians, and supercentenarians discussed in this chapter were born during the partition period.

Russian Poland, also known as Congress Poland, bordered Russia on the east, and consisted of the modern-day voivodeships of Masovia, Lodz, Swietokrzyskie, Podlaskie, and Lublin, parts of the modern-day voivodeships of, Kuyavia-Pomerania, Greater Poland, and Silesia (Fig. 11.1), as well as the western part of modern Lithuania and Belarus. German Poland was formed of Pomerania, Warmia-Masuria and the remaining parts of Greater Poland and Silesia. Austrian Poland was in the south, and included the modern-day voivodeships of Lesser Poland and Subcarpathia, as well as some territory in what is modern-day Ukraine.

The Poland's People Republic was established at the end of World War II, and The Round Table Agreement in 1989 created the independent Republic of Poland that exists today. The system of administrative areas called voivodeships went into effect in 1999 (Fig. 11.2). Official population and death statistics for the Republic of Poland are available only since 2004.

\footnotetext{
W. J. Kroczek ( $\square)$

Gerontology Research Group, Tarnowskie Góry, Silesia, Poland 


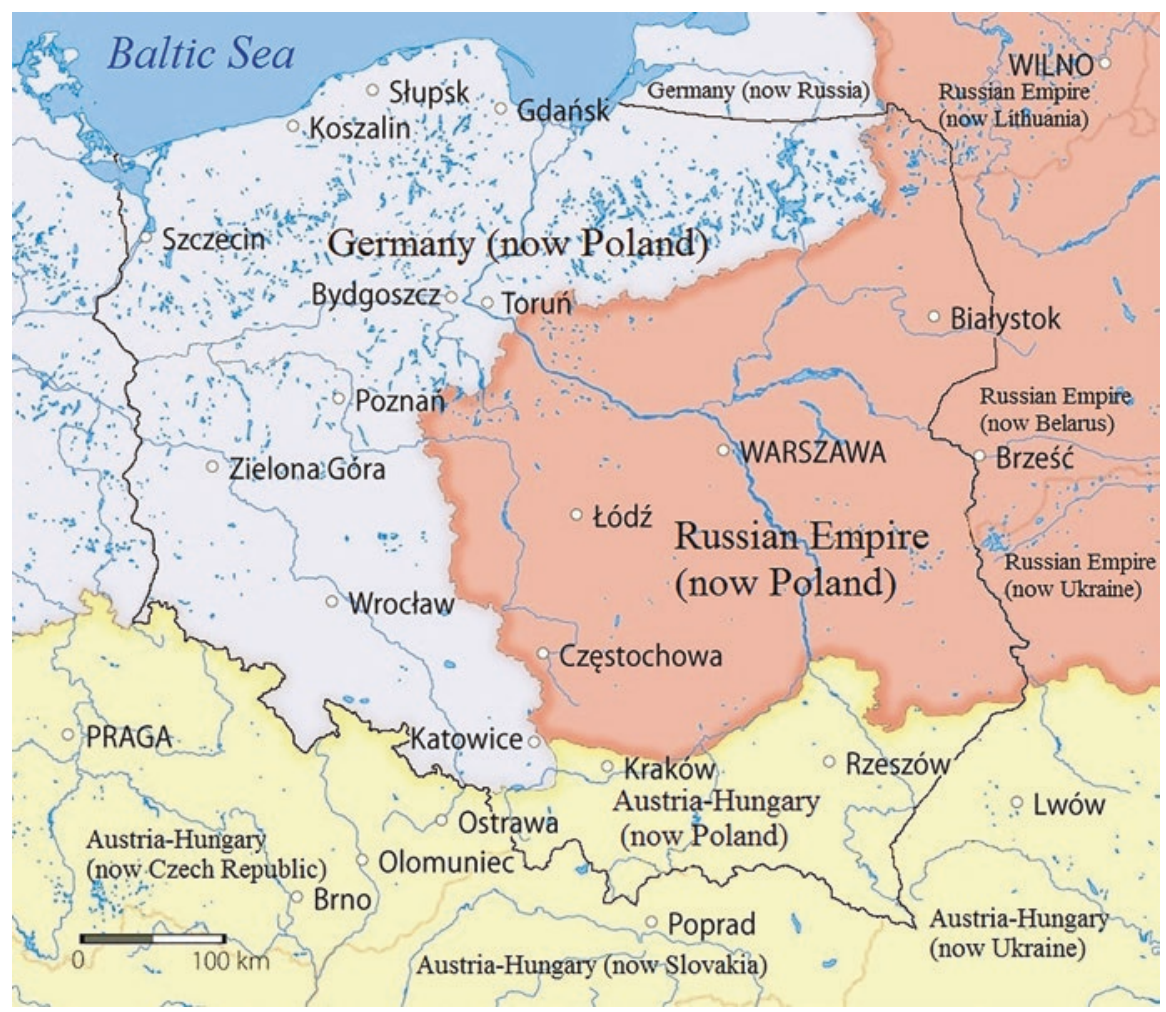

Fig. 11.1 Polish lands between 1815 and 1918, administrated by three empires, with the modern borders of Poland marked in black

\subsection{Birth and Marriage Registration}

Birth and marriage records play an essential role in the validation of assertions of achievement of extreme age. Fortunately, and contrary to what one might expect, the great majority of registration records have survived the two world wars. Even most of the registry records from Warsaw survived, in spite of the utter destruction of the city after the unsuccessful Warsaw Uprising in 1944.

Similarly to the Nordic countries, for centuries the registration of births, marriages, and deaths in Poland was a church function - whether Lutheran, Roman Catholic, Greek Orthodox, Orthodox, or Jewish - and the registration records were kept in the locality where the event took place (Skytthe et al. 2010). Depending on where and when they were created, the records might be written in Polish, in German, in Russian, or in Latin.

With the beginning of the secular registration of events in 1946, these registration records were transferred to local government registry offices, the USC (Urząd Stanu Cywilnego). Other arrangements were made for the church registration records for 


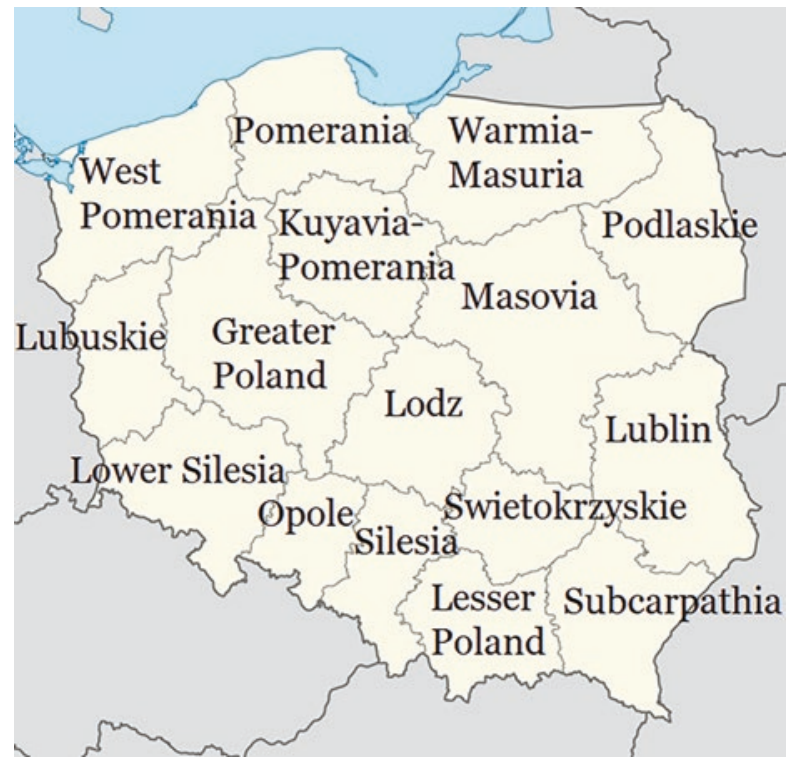

Fig. 11.2 Administrative divisions of Poland (Voivodeships)

the former Eastern territories, which are today parts of Lithuania, Belarus, and Ukraine. When a birth is 100 years in the past or a marriage or death is 80 years in the past, the record is forwarded to a local archive unit, or, in the case of the former Eastern territories, to the Central Archives of Historical Records. Only recently has the Polish government begun to convert the historical registration records to an electronic database.

The birth registration record in Congress Poland (Russian Poland) was written in narrative style and contained information on the newborn, its parents and their professions, and the date and place of birth. The Russian administration has also reinstated the Julian calendar. As a result, both the Gregorian and Julian calendar were used in Congress Poland. The narrative might be in Polish, using the Latin alphabet, or in Russian, using the Cyrillic alphabet. Sometimes a marriage record was appended, such as in the sample birth record shown in Fig. 11.3. The appended marriage record is useful in validation efforts.

The birth registration record in German Poland was also written in a narrative style. The German language and Gregorian calendar were used. Furthermore, besides recordation in church records, the birth was also recorded in the local branch of the Office of Vital Records, as was the practice throughout the German Empire, with basic information as well as information on the parents' professions and religions (Maier and Scholz 2010). Cooperation between Germany and Poland in validation activity is highly desirable, since only a small amount of these records have made their way over to Germany, and there is evidence from the Gerontology Research Group (GRG) (Cf. Reference \#1) that a significant number of alleged German supercentenarians were, in fact, born in German Poland. 


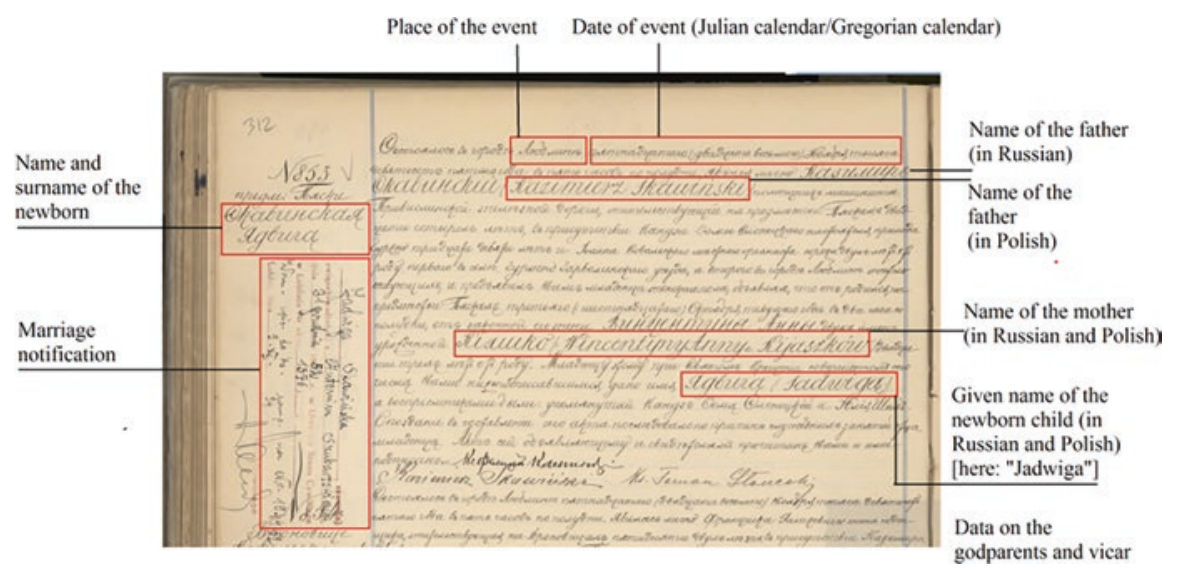

Fig. 11.3 Sample birth record from Congress Poland

In Austrian Poland, unlike the rest of Poland, the birth registration record had a fixed format, rather than a narrative form, and was limited to basic information. The language was sometimes Polish, sometimes German, and sometimes Ukrainian, with its Cyrillic alphabet.

This diversity in language, content, and form of birth registration records poses a challenge for the researcher attempting to validate alleged extreme ages. Another formidable hurdle is the strict Polish privacy law: access to such records is restricted to the subjects of these records, their family members, and institutions with a legally justified interest.

\subsection{Other Records}

Censuses in independent Poland were conducted in 1921 and 1931, but the 1941 census did not take place because of the outbreak of World War II. Censuses were conducted regularly since after the war, the most recent ones in 2002 and 2011. We will present in this chapter the official counts of the extreme-aged population from the censuses and post-census estimates, with a strong caveat about age misstatement.

Since 1979 every Polish citizen is assigned a unique 11-digit number by the Universal Electronic System for Registration of the Population, called PESEL (Powszechny Elektroniczny System Ewidencji Ludności). The PESEL number has the format YYMMDDZZZXQ, where YYMMDD is the date of birth (the MM coding reflects century of birth in addition to month of birth), ZZZX is a personal identification number where $X$ is an even number for females and an odd number for males, and Q is a "check digit". The PESEL database is maintained by the Ministry of Digitalization, with access limited to scientific organizations. 


\subsection{Centenarians in Poland}

Official counts of living centenarians and deaths among centenarians, by single year of age, gender, and voivodeship (i.e., administrative regions) are available for years beginning with 2004 - but with significant data quality issues, as we will describe.

The latest count of living centenarians, published by the Ministry of Interior, is 4200 as of June 2015. The greatest number of centenarians are in the most populous voivodeships: Masovia has 724, Greater Poland 417, Lesser Poland 378 and Silesia 376 (Fig. 11.4). Szukalski (2002) has noted that Poland exhibits the tendency found in several developed countries for the number of centenarians to double over a 10 -year period.

Similarly, the number of centenarian deaths nearly doubled from 2004 to 2014, as can be seen from the counts of deaths published by the Main Statistical Office (Pol. Główny Urząd Statystyczny) and displayed in Table 11.1. It is interesting to note the dip in the number of centenarian deaths at ages 100 and 101 from 2015 to 2016, which happens to also be the case in the Czech Republic, according to data from the Czech Social Security Bureau (cf. Reference \#16). One might speculate that this corresponds to a dip in the number of births 100 and 101 years earlier - during World War I.

From Figs. 11.5 and 11.6, respectively, one sees that in these official Ministry of Interior data, the voivodeship of Podlaskie has both the highest percentage male among its centenarians and the highest number of centenarians per one million inhabitants. The latter finding is surprising given that Podlaskie is in the coldest part of the country, and the finding is, in fact, suggestive of data quality issues.

Counts of centenarians in Poland are available back to the time of the first modern Polish census, in 1921 (see Table 11.2). However, meaningful comparisons over time are problematic, partly because of changing borders and population losses due to war, but mostly because of serious data quality issues. One might be tempted to hope that the latest censuses, at least, provide reliable data, but the rather low centenarian sex ratios (= number of females/number of males), in comparison to countries with good-quality data, suggest that quality issues remain formidable.

PolStu2001 was an evaluation study of Poland's population statistics, under the leadership of Dr. Małgorzata Mossakowska. PolStu2001 identified two regions

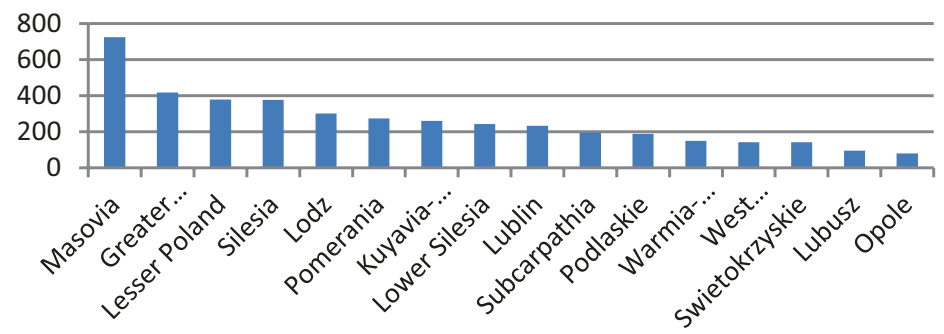

Fig. 11.4 Number of living centenarians by Voivodeship (June 2015) 
Table 11.1 Deaths among centenarians by age and year

\begin{tabular}{l|r|r|r|r|r|r|r|r|r|r|r|r|r|}
\hline & 2004 & 2005 & 2006 & 2007 & 2008 & 2009 & 2010 & 2011 & 2012 & 2013 & 2014 & 2015 & 2016 \\
\hline 100 & $\mathbf{2 9 9}$ & $\mathbf{3 0 3}$ & $\mathbf{3 2 8}$ & $\mathbf{3 6 7}$ & $\mathbf{3 4 1}$ & $\mathbf{4 5 2}$ & $\mathbf{4 8 2}$ & $\mathbf{4 5 4}$ & $\mathbf{5 1 3}$ & $\mathbf{5 1 7}$ & $\mathbf{5 7 7}$ & $\mathbf{5 7 3}$ & $\mathbf{4 1 0}$ \\
\hline 101 & $\mathbf{1 8 3}$ & $\mathbf{2 4 0}$ & $\mathbf{2 0 2}$ & $\mathbf{2 2 8}$ & $\mathbf{2 7 7}$ & $\mathbf{3 0 8}$ & $\mathbf{3 1 3}$ & $\mathbf{3 0 7}$ & $\mathbf{3 7 1}$ & $\mathbf{3 4 9}$ & $\mathbf{3 5 0}$ & $\mathbf{4 3 2}$ & $\mathbf{3 8 4}$ \\
\hline 102 & $\mathbf{1 3 9}$ & $\mathbf{1 2 8}$ & $\mathbf{1 0 0}$ & $\mathbf{1 2 4}$ & $\mathbf{1 4 6}$ & $\mathbf{1 6 0}$ & $\mathbf{2 0 7}$ & $\mathbf{1 9 8}$ & $\mathbf{2 1 9}$ & $\mathbf{2 2 4}$ & $\mathbf{2 3 5}$ & $\mathbf{2 5 4}$ & $\mathbf{2 6 7}$ \\
\hline 103 & $\mathbf{6 6}$ & $\mathbf{7 7}$ & $\mathbf{6 8}$ & $\mathbf{9 3}$ & $\mathbf{1 1 3}$ & $\mathbf{1 0 3}$ & $\mathbf{1 3 0}$ & $\mathbf{1 2 0}$ & $\mathbf{1 2 2}$ & $\mathbf{1 3 3}$ & $\mathbf{1 4 0}$ & $\mathbf{1 7 3}$ & $\mathbf{1 7 3}$ \\
\hline 104 & $\mathbf{4 7}$ & $\mathbf{5 6}$ & $\mathbf{4 8}$ & $\mathbf{6 3}$ & $\mathbf{5 0}$ & $\mathbf{6 4}$ & $\mathbf{7 1}$ & $\mathbf{7 2}$ & $\mathbf{8 6}$ & $\mathbf{8 6}$ & $\mathbf{8 5}$ & $\mathbf{1 0 6}$ & $\mathbf{1 0 5}$ \\
\hline 105 & $\mathbf{1 0}$ & $\mathbf{2 5}$ & $\mathbf{2 4}$ & $\mathbf{3 1}$ & $\mathbf{3 3}$ & $\mathbf{2 4}$ & $\mathbf{3 8}$ & $\mathbf{3 0}$ & $\mathbf{4 2}$ & $\mathbf{3 8}$ & $\mathbf{3 9}$ & $\mathbf{6 8}$ & $\mathbf{6 1}$ \\
\hline 106 & $\mathbf{8}$ & $\mathbf{1 2}$ & $\mathbf{1 7}$ & $\mathbf{1 3}$ & $\mathbf{2 4}$ & $\mathbf{1 6}$ & $\mathbf{2 5}$ & $\mathbf{2 1}$ & $\mathbf{2 7}$ & $\mathbf{3 0}$ & $\mathbf{1 9}$ & $\mathbf{2 6}$ & $\mathbf{2 6}$ \\
\hline 107 & $\mathbf{4}$ & $\mathbf{5}$ & $\mathbf{6}$ & $\mathbf{5}$ & $\mathbf{8}$ & $\mathbf{7}$ & $\mathbf{9}$ & $\mathbf{1 0}$ & $\mathbf{1 0}$ & $\mathbf{1 0}$ & $\mathbf{1 3}$ & $\mathbf{1 6}$ & $\mathbf{1 5}$ \\
\hline 108 & $\mathbf{4}$ & $\mathbf{4}$ & $\mathbf{4}$ & $\mathbf{4}$ & $\mathbf{3}$ & $\mathbf{8}$ & $\mathbf{3}$ & $\mathbf{3}$ & $\mathbf{7}$ & $\mathbf{7}$ & $\mathbf{6}$ & $\mathbf{1 1}$ & $\mathbf{7}$ \\
\hline 109 & $\mathbf{4}$ & $\mathbf{1}$ & $\mathbf{1}$ & $\mathbf{5}$ & $\mathbf{1}$ & $\mathbf{4}$ & $\mathbf{3}$ & $\mathbf{3}$ & $\mathbf{4}$ & $\mathbf{4}$ & $\mathbf{5}$ & $\mathbf{2}$ & $\mathbf{8}$ \\
\hline $110+$ & $\mathbf{4}$ & $\mathbf{6}$ & $\mathbf{5}$ & $\mathbf{8}$ & $\mathbf{5}$ & $\mathbf{3}$ & $\mathbf{4}$ & $\mathbf{3}$ & $\mathbf{8}$ & $\mathbf{7}$ & $\mathbf{6}$ & $\mathbf{3}$ & $\mathbf{7}$ \\
\hline Overall & 768 & 857 & 803 & 941 & 1001 & 1149 & 1285 & 1221 & 1409 & 1405 & 1475 & 1664 & 1463 \\
\hline
\end{tabular}

Source: Main Statistical Office (Pol. Główny Urząd Statystyczny (GUS))

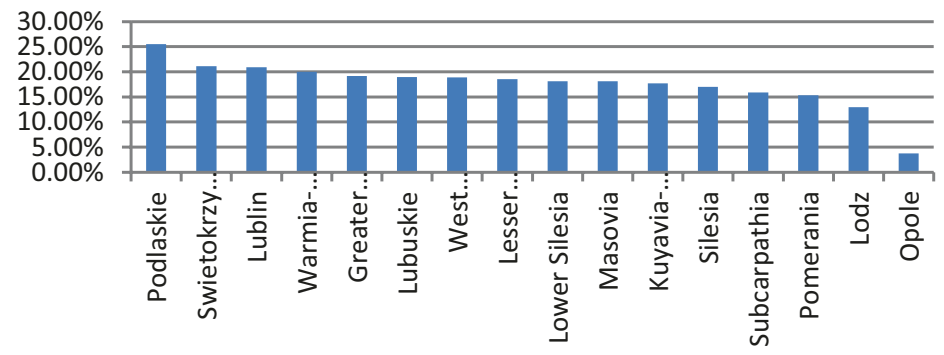

Fig. 11.5 Percentage of centenarians who are male, by Voivodeship (June 2015)

where age exaggeration was particularly pronounced (Fig. 11.7). One is the aforementioned Podlaskie Voivodeship: with its civil and parish registries destroyed, the allegations of its largely rural population formed the basis of its age statistics. The other is the western and northern territory which became part of Poland after 1945. Here much of the problem is from the "repatriates" - persons who were living in present-day Lithuania, Belarus and Ukraine and moved into this territory after the war, typically during the First Repatriation (1945-47) and the Second Repatriation (1953-57). Movement from one country to another necessitated new documents, and apparently age was not then reported very accurately. Mossakowska calculated that the number of repatriate centenarians was three times what was expected, despite no known reason why this group should enjoy greater survival to extreme old age. Parenthetically, this phenomenon of poorer quality of age data for immigrant populations exists in other counties, as well, such as Sweden.

The repatriates cannot be identified in public records because of Poland's privacy laws. The best that can be done, using Fig. 11.7, is to recognize that there are two areas in Poland, which we'll call A and B, one with better age data and the other with poorer age data. Poland B consists of Podlaskie and the northern and western 


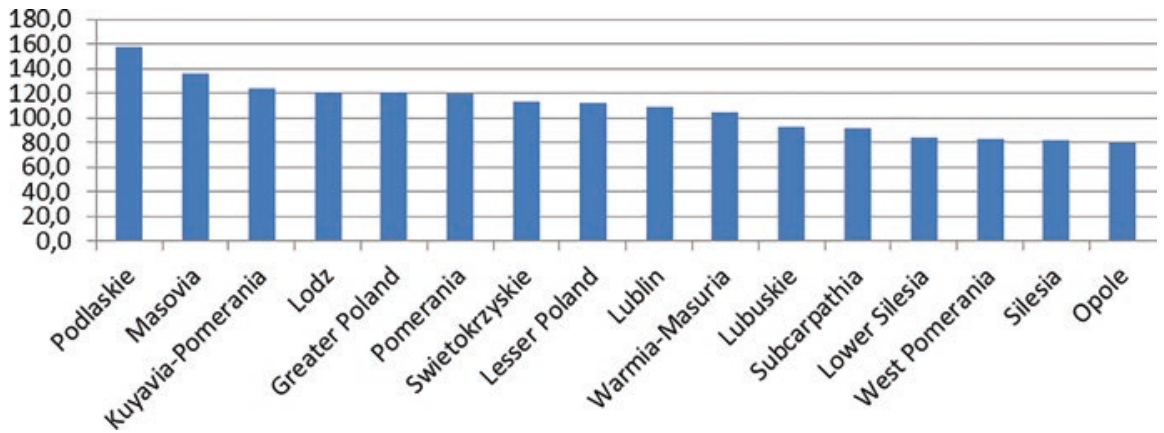

Fig. 11.6 Number of centenarians per one million inhabitants, by Voivodeship (June 2015)

Table 11.2 Number of centenarians, various polish censuses

\begin{tabular}{l|l|l|l|l|l}
\hline Year & Overall & Men & Women & Sex ratio & Per one million citizens \\
\hline 1921 & 2560 & 1111 & 1449 & 1.30 & 94.2 \\
\hline 1931 & 2617 & 1160 & 1457 & 1.26 & 82.0 \\
\hline 1950 & 320 & 94 & 226 & 2.40 & 12.7 \\
\hline 1960 & 432 & 74 & 358 & 4.84 & 14.5 \\
\hline 1970 & 330 & 68 & 262 & 3.85 & 10.1 \\
\hline 1978 & 424 & 85 & 339 & 3.99 & 12.1 \\
\hline 1988 & 1564 & 363 & 1201 & 3.31 & 413 \\
\hline 2002 & 1541 & 326 & 1215 & 3.73 & 40.3 \\
\hline
\end{tabular}

Source: Szukalski (2002)

voivodeships of Pomerania, West Pomerania, Warmia-Masuria, Lubuskie, Opole, and Lower Silesia. When possible, studies on centenarians and semi-centenarians which are based on official statistics should be confined to Poland A.

An interesting conclusion of the PolStu2001 program was that there was no person living in 2005 with a proven age of 110 or more (Mossakowska and Jaczewska 2006).

\subsection{Semi-supercentenarians}

Counts of deaths at ages $105+$ and counts of living persons at the same ages are available from the Main Statistical Office (GUS), Social Security Bureau (ZUS), Agricultural Social Security (KRUS) and the Ministry of Interior, respectively, for each year 2004 through 2016, by single year of age, year of birth, gender, and voivodeship. These counts are displayed by voivodeship in Fig. 11.8 for deaths only and by year of birth in Fig. 11.9. Almost half of the deaths were to residents of the northern voivodeships belonging to Poland B (Podlaskie, Pomerania, West Pomerania and Warmia-Masuria). The counts by year of birth form a generally 


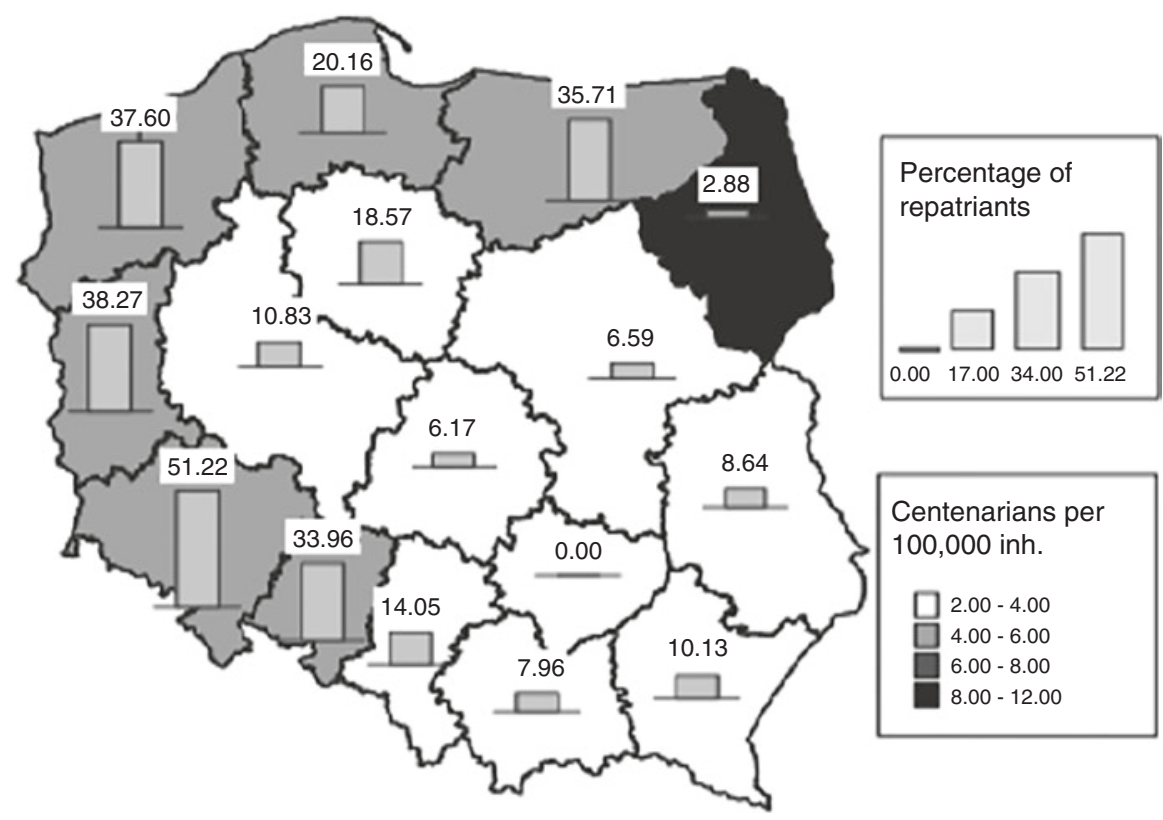

Fig. 11.7 Percentage of centenarians born beyond Poland's borders and number of centenarians per 100,000 persons (Mossakowska and Szybalska 2008)

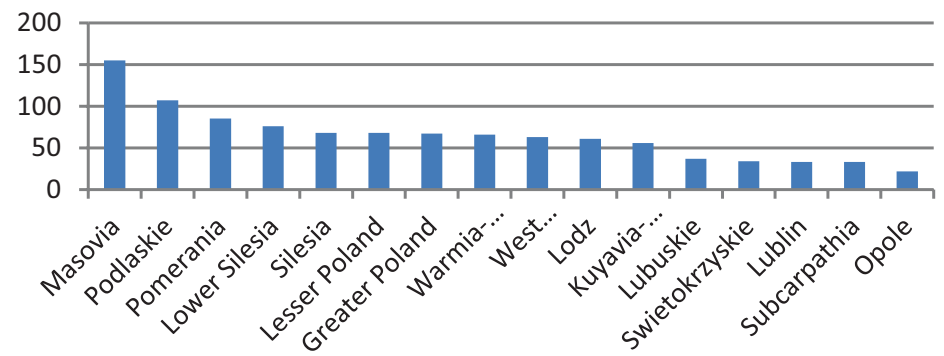

Fig. 11.8 Recorded semi-supercentenarian deaths by Voivodeship (2004-2016 data)

increasing sequence, with the number born in 1910 almost twice the number born in 1903. The total number of semisupercentenarians is 1030 .

Using the counts for Poland A only (totalling 556 semisupercentenarians), we calculated mortality rates from age 105 to the highest age recorded in these data, age 111 (Fig. 11.10). The rate at age 105 is slightly below 0.5, the rates at ages 106 and 107 slightly above 0.5 , and the rates beyond age 107 are higher. Extreme-age mortality seems to be similar to old-age mortality in Germany, although somewhat higher - perhaps because of the colder Polish climate (Fig. 11.10). The data for Germany come from the research conducted by the Gerontology Research Group's 


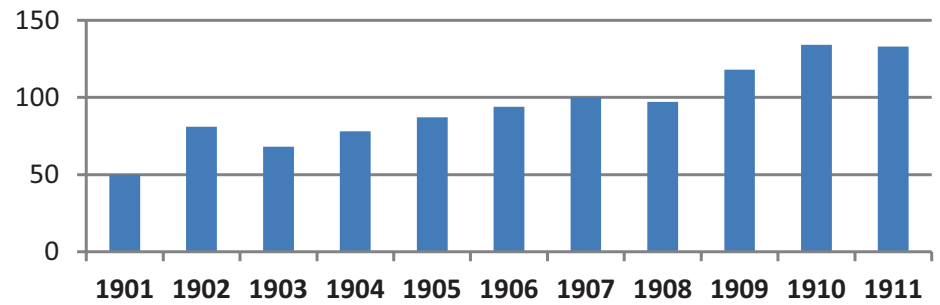

Fig. 11.9 Recorded semi-supercentenarians by year of birth (including the living)

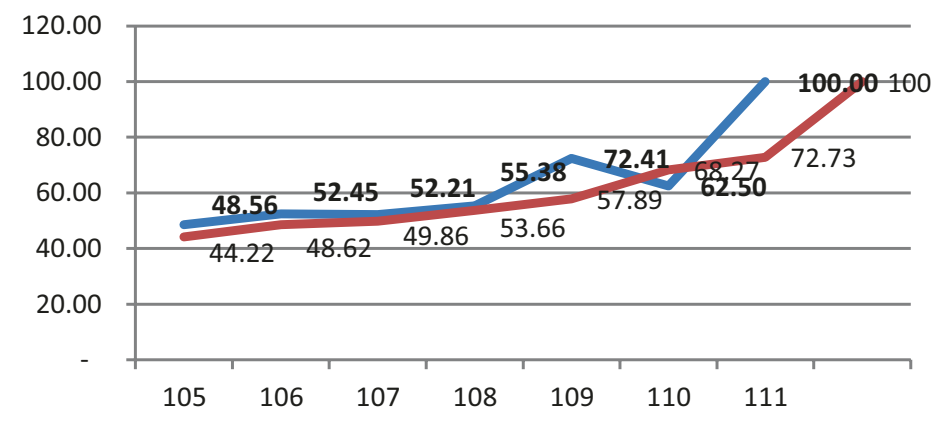

Fig. 11.10 Mortality rates of Polish (blue) and German (red) semisupercentenarians (Data for Germany from the Gerontology Research Group's German correspondents)

German correspondents, Messrs. Thomas Breining and Stefan Jamin (Gerontology Research Group 1990-2017) (Cf. Reference \#2).

Since 2012 we have expended great effort to find allegations of achievement of ages 105 and over and to critically evaluate those claims. While we have made much progress, the work is incomplete and we present our research findings only for supercentenarians, in the next section.

\subsection{The Emergence of Supercentenarians in Poland}

\subsubsection{Description of Our Research}

From the Local Data Bank database (Bank Danych Lokalnych) developed by the GUS, we have the number of deaths between 2004 and 2016 at recorded ages 110+, by single year of age and the voivodeship where the death occurred. The total is 69 ; the question, of course, is: what is the quality of these data?

We set out to (a) identify alleged supercentenarians and (b) verify the allegations of achievement of this elevated age, using modern scientific standards of age validation (Thoms 1873) from a combination of early-life evidence (issued within the person's first 20 years), middle-life evidence (which might show a name change), 
and late-life evidence. (Poulain 2010) When the set of evidence was consistent and sufficient, the case was judged to be validated (Jeune and Vaupel 1999). Considering that access to the Polish census data is not possible, obtaining the original birth registration was essential. Often we needed the cooperation of the subject's family to obtain the necessary evidence.

The identification of potential supercentenarians was difficult. The GUS records are kept strictly confidential. There is no alternative but to search in secondary sources using library and newspaper resources and to contact local registry offices for the needed evidence. Furthermore, extremely aged people in Poland tend to avoid attention.

\subsubsection{Reported and Validated Supercentenarians Who Died in Present-Day Poland}

It is an understatement that supercentenarians are very rare. One might expect one supercentenarian to emerge from a cohort of 1000 centenarians, using an assumption that the annual probability of mortality at ages $100+$ is about 0.5 (Young et al. 2009a, b, Kannisto 1994). Very roughly speaking, if there were 15,441 deaths to recorded centenarians in Poland between 2004 and 2016, one might expect about 15 supercentenarian deaths over the same period. Not only is the count of 69 supercentenarians several times what might be expected, but 25 of the 69 were males -a very unlikely scenario.

A comparison with the German data for 2004-2014 (data for Germany for years after 2014 are not available) provides further evidence that these reported data are implausible. For one thing, the number of German supercentenarians is less than the number for Poland, even though Germany has more centenarians than Poland. For another, Germany's validated supercentenarians are almost all women (93\%) (Fig. 11.11).

In fact, most of the deaths at recorded ages 110+ occurred in Poland B, especially in Podlaskie (14, including 6 males) and Warmia-Masuria (10), recalling for us

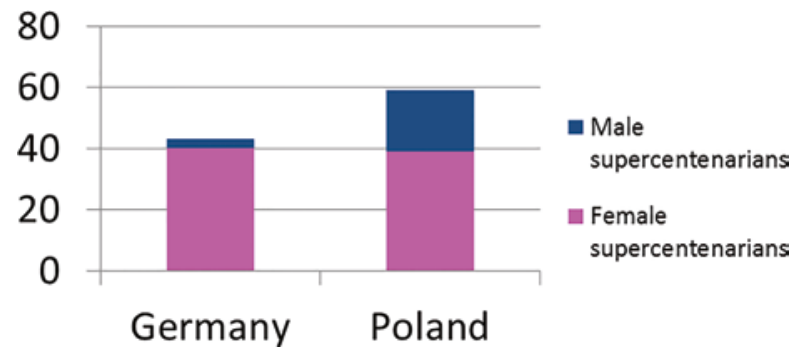

Fig. 11.11 Recorded GUS supercentenarian deaths in Poland between 2004 and 2014 and validated/pending GRG deaths for Germany (Cf. reference \#1) in the same period 


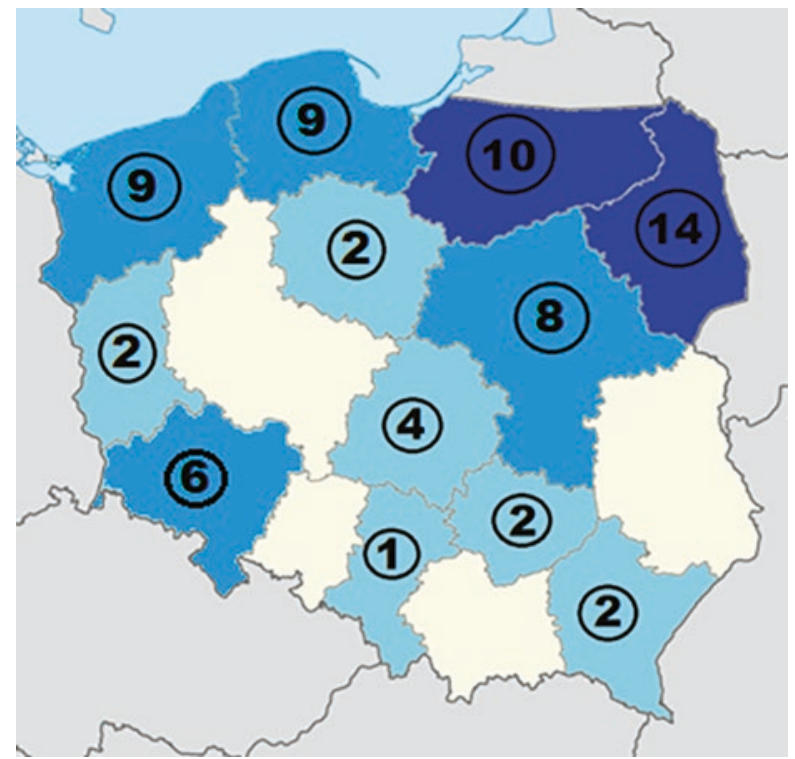

Fig. 11.12 Deaths at age 110+ recorded in Poland, by Voivodeship (years 2004-2016)

Mossakowska's thesis about significant age exaggeration in Podlaskie and among repatriates (Fig. 11.12). In particular, is it possible that cold, remote Podlaskie, with a total population of 1.2 million, could have more supercentenarians than Austria and Switzerland?

While validation efforts are ongoing, as of this writing (September 2017) there are 14 people - all female - who died or are alive in Poland and, beyond reasonable doubt, attained age 110 (Table 11.3; Fig. 11.13). It is perhaps noteworthy that this number is more in line with our expectations given the number of Polish centenarians.

In comparison with other countries in Western and Southern Europe, this number of validated Polish supercentenarians is less than would be expected. The explanation may lie in the troubled history of Poland - population losses during the two world wars, extensive emigration, and general political and economic instability. Now that conditions have improved, we may expect longevity in Poland to become comparable to longevity in other European countries.

The earliest validated supercentenarian is Rozalia Milczarek (1869-1981) of Niedoradz, Lubuskie Voivodeship, who lived 111 years 122 days. She was born before Augusta Holtz (1871-1986), who died in the United States and was thought to be the earliest supercentenarian born in present-day Poland, as well as before the earliest validated supercentenarian who died in the Nordic countries, Wilhelmine Sande (1874-1986). (Skytthe, Hervonen, Ruisdael, and Jeune, 2010).

The next validated supercentenarian in Poland, Jadwiga Zołotucho (1892-2003), who last resided in Ostróda, Warmia-Masuria and was born in Vilnius, Russian 
Table 11.3 Validated supercentenarians in Poland (listed in birth order) ("as of Sept. 2017)

\begin{tabular}{|c|c|c|c|c|c|c|}
\hline Name & Birthdate & $\begin{array}{l}\text { Death } \\
\text { date }\end{array}$ & Years & Days & Country of birth & Last residence \\
\hline $\begin{array}{l}1 \quad \text { Rozalia } \\
\text { Milczarek }\end{array}$ & $\begin{array}{l}\text { Sept. 5, } \\
1869\end{array}$ & $\begin{array}{l}\text { Jan. 5, } \\
1981\end{array}$ & 111 & 122 & $\begin{array}{l}\text { Russian Empire } \\
\text { (now Poland) }\end{array}$ & Poland (Lubuskie) \\
\hline $\begin{array}{l}2 \text { Jadwiga } \\
\text { Zolotucho }\end{array}$ & $\begin{array}{l}\text { Mar. 29, } \\
1892\end{array}$ & $\begin{array}{l}\text { Jury } 1, \\
2003\end{array}$ & 111 & 94 & $\begin{array}{l}\text { Russian Empire } \\
\text { (now Lithuania) }\end{array}$ & $\begin{array}{l}\text { Poland } \\
\text { (Warmia-Masuria) }\end{array}$ \\
\hline $\begin{array}{l}3 \text { Marianna } \\
\text { Smolarczyk }\end{array}$ & $\begin{array}{l}\text { Feb. 16, } \\
1897\end{array}$ & $\begin{array}{l}\text { Mar. } \\
30 \\
2007 \\
\end{array}$ & 110 & 42 & $\begin{array}{l}\text { Russian Empire } \\
\text { (now Poland) }\end{array}$ & $\begin{array}{l}\text { Poland } \\
\text { (Świẹtokrzyskie) }\end{array}$ \\
\hline $\begin{array}{l}4 \quad \text { Ludwika } \\
\text { Kosztyla }\end{array}$ & $\begin{array}{l}\text { Aug. 3, } \\
1897\end{array}$ & $\begin{array}{l}\text { Dec. } 1, \\
2008\end{array}$ & 111 & 120 & $\begin{array}{l}\text { Austria- } \\
\text { Hungary (now } \\
\text { Poland) }\end{array}$ & $\begin{array}{l}\text { Poland } \\
\text { (Subcarpathia) }\end{array}$ \\
\hline $\begin{array}{l}5 \text { Michalina } \\
\text { Wasilewska }\end{array}$ & $\begin{array}{l}\text { Dec. 21, } \\
1898\end{array}$ & \begin{tabular}{|l} 
Jan. 3, \\
2010
\end{tabular} & 111 & 13 & $\begin{array}{l}\text { Russian Empire } \\
\text { (now Poland) }\end{array}$ & Poland (Masovia) \\
\hline $\begin{array}{l}6 \quad \text { Wanda } \\
\text { Wierzchleyska }\end{array}$ & $\begin{array}{l}\text { Mar. 3, } \\
1900\end{array}$ & $\begin{array}{l}\text { Jan. 14, } \\
2012\end{array}$ & 111 & 317 & $\begin{array}{l}\text { Austria- } \\
\text { Hungary (now } \\
\text { Ukraine) }\end{array}$ & Poland (Masovia) \\
\hline $\begin{array}{l}7 \text { Julianna } \\
\text { Garbarz }\end{array}$ & \begin{tabular}{|l|} 
June 22, \\
1900
\end{tabular} & \begin{tabular}{|l|} 
Jury 18 \\
2010
\end{tabular} & 110 & 26 & $\begin{array}{l}\text { Russian Empire } \\
\text { (now Poland) }\end{array}$ & \begin{tabular}{|l|}
$\begin{array}{l}\text { Poland } \\
\text { (Świẹtokrzyskie) }\end{array}$ \\
\end{tabular} \\
\hline $\begin{array}{l}8 \quad \text { Marianna } \\
\text { Misiewicz }\end{array}$ & $\begin{array}{l}\text { Jan. } 26 . \\
1902\end{array}$ & \begin{tabular}{|l|} 
June \\
28, \\
2012 \\
\end{tabular} & 110 & 154 & $\begin{array}{l}\text { Russian Empire } \\
\text { (now Poland) }\end{array}$ & Poland (Podlaskie) \\
\hline $\begin{array}{l}9 \text { Józefa } \\
\text { Karczewska }\end{array}$ & \begin{tabular}{|l|} 
Nov. 23, \\
1902 \\
\end{tabular} & \begin{tabular}{|l|} 
Jan. 18, \\
2013 \\
\end{tabular} & 110 & 56 & $\begin{array}{l}\text { Russian Empire } \\
\text { (now Poland) }\end{array}$ & Poland (Łódż) \\
\hline $\begin{array}{l}10 \quad \text { Józefa } \\
\text { Stanislawa Szyda }\end{array}$ & \begin{tabular}{|l|} 
Mar. 11, \\
1903 \\
\end{tabular} & \begin{tabular}{|l|} 
May 1, \\
2013 \\
\end{tabular} & 110 & 51 & $\begin{array}{l}\text { Russian Empire } \\
\text { (now Poland) }\end{array}$ & Poland (Łódż) \\
\hline $\begin{array}{l}11 \text { Aleksandra } \\
\text { Dranka }\end{array}$ & $\begin{array}{l}\text { Oct. 3, } \\
1903\end{array}$ & $\begin{array}{l}\text { Apr. 29, } \\
2014\end{array}$ & 110 & 208 & $\begin{array}{l}\text { Austria- } \\
\text { Hungary (now } \\
\text { Poland) }\end{array}$ & $\begin{array}{l}\text { Poland } \\
\text { (Subcarpathia) }\end{array}$ \\
\hline $\begin{array}{l}12 \text { Jadwiga } \\
\text { Szubartowicz }\end{array}$ & \begin{tabular}{|l} 
Oct. 16, \\
1905
\end{tabular} & \begin{tabular}{|l|} 
Jury 20, \\
2017 \\
\end{tabular} & 111 & 277 & $\begin{array}{l}\text { Russian Empire } \\
\text { (now Poland) }\end{array}$ & Poland (Lublin) \\
\hline $\begin{array}{l}13 \text { Tekla } \\
\text { Juniewicz }\end{array}$ & $\begin{array}{l}\text { June 10, } \\
1906\end{array}$ & living & $111^{*}$ & & $\begin{array}{l}\text { Austria- } \\
\text { Hungary (now } \\
\text { Ukraine) }\end{array}$ & Poland (Silesia) \\
\hline $\begin{array}{l}14 \text { Czeslawa } \\
\text { Lasiewicz }\end{array}$ & $\begin{array}{l}\text { Jan. 14, } \\
1907\end{array}$ & living & $110^{*}$ & & $\begin{array}{l}\text { Russian Empire } \\
\text { (now Poland) }\end{array}$ & Poland (Podlaskie) \\
\hline
\end{tabular}

Significance codes: *Age of living people given as of Sept. 2017

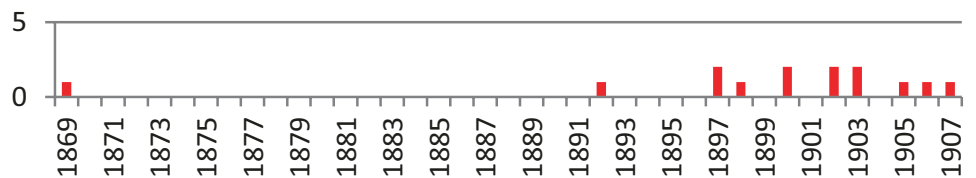

Fig. 11.13 Validated supercentenarians in Poland by year of birth (as of Sept. 2017) 


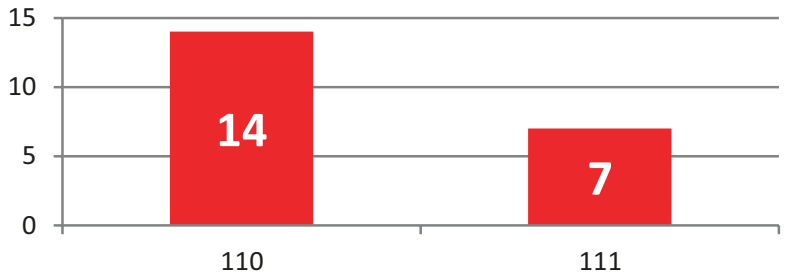

Fig. 11.14 Validated supercentenarians in Poland: number achieving each age (as of Sept. 2017)

Empire (now Lithuania), died 22 years after Rozalia Milczarek. It is surprising that there is no death to a validated supercentenarian in the intervening 22 years; perhaps we will find one or more as we proceed with our validation efforts.

Seven of the validated supercentenarians achieved age 111 (consistent with a mortality probability near 50\%) (Fig. 11.14), but none achieved age 112 (although two are still living). By comparison, there are several deaths at ages 112 or more in the GUS unverified data, presumably often for repatriates. The longest-lived supercentenarian is Wanda Wierzchleyska (1900-2012) of Warsaw, who lived 111 years 317 days. Incidentally, Mrs. Wierzchleyska is a repatriate, having been born in Lwów, in present-day Ukraine. Clearly then it would have been a mistake to assume that none of the repatriates reached age 110 .

Table 11.3 lists the 14 validated supercentenarians in birth order. So far, no more than two were born in any year. The first time that two Polish supercentenarians were alive at the same time was in 2010 - Wanda Wierzchleyska (1900-2012) and Julianna Garbacz (1900-2010), and the first time that three were alive at the same time was in the first half of 2017 (www.najstarsipolacy.pl).

The supercentenarian whose achievement was the first one that we were able to document is Marianna Misiewicz (1902-2012), while the first supercentenarian to be validated while still alive is Aleksandra Dranka (1903-2014), from the village of Harklowa, Subcarpathia. The first validated supercentenarian from the present-day Lublin Voivodeship is Mrs. Jadwiga Szubartowicz (1905-2017). She was residing in St. Petersburg in 1917 at aged 12 and remembered the Russian Revolution quite clearly. The author met and interviewed each of the last four supercentenarians on the list below and contacted with the families of deceased supercentenarians.

Most of our validated supercentenarian cases are in the eastern Voivodeships (Fig. 11.15). Two of the eastern Voivodeships, Świętokrzyskie and Subcarpathia, had two validated supercentenarians each, which actually matches the number recorded for them in the GUS statistics. These two regions have a very small fraction of repatriates in their elderly populations.

The two supercentenarians from Świętokrzyskie Voivodeship come from the counties of Kielce and Końskie. Namely, Marianna Smolarczyk, (1897-2007) was born and died in Łubno (Kielce County), and Julianna Garbacz (1900-2010) was born in Wólka Zychowa and died in Końskie (Końskie County). Of the 108 total centenarians living in the Voivodeship in February 2016, 50 lived in these two counties (Fig. 11.16). 


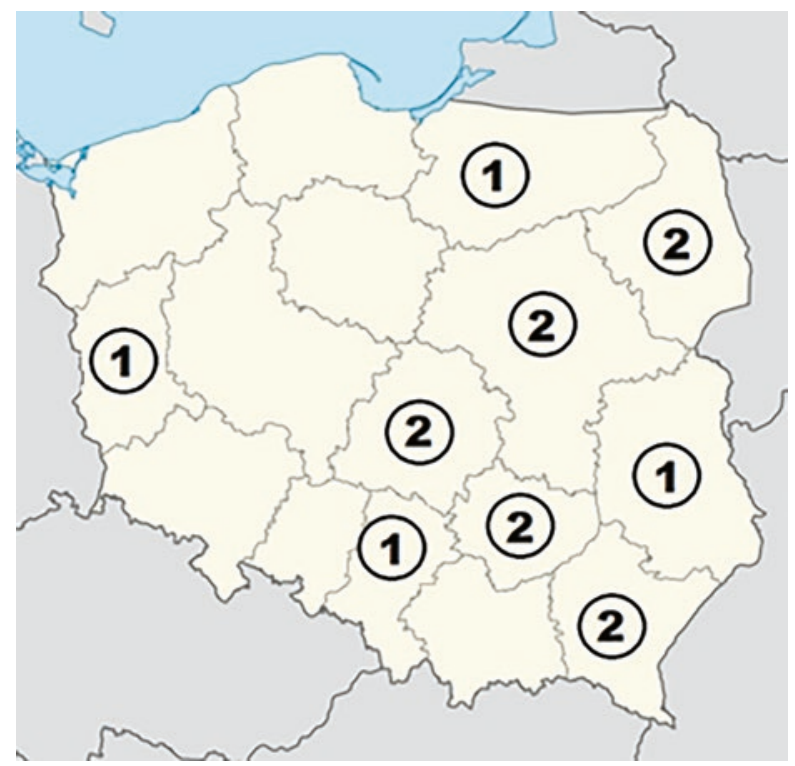

Fig. 11.15 Distribution of validated supercentenarians by Voivodeship of last residence

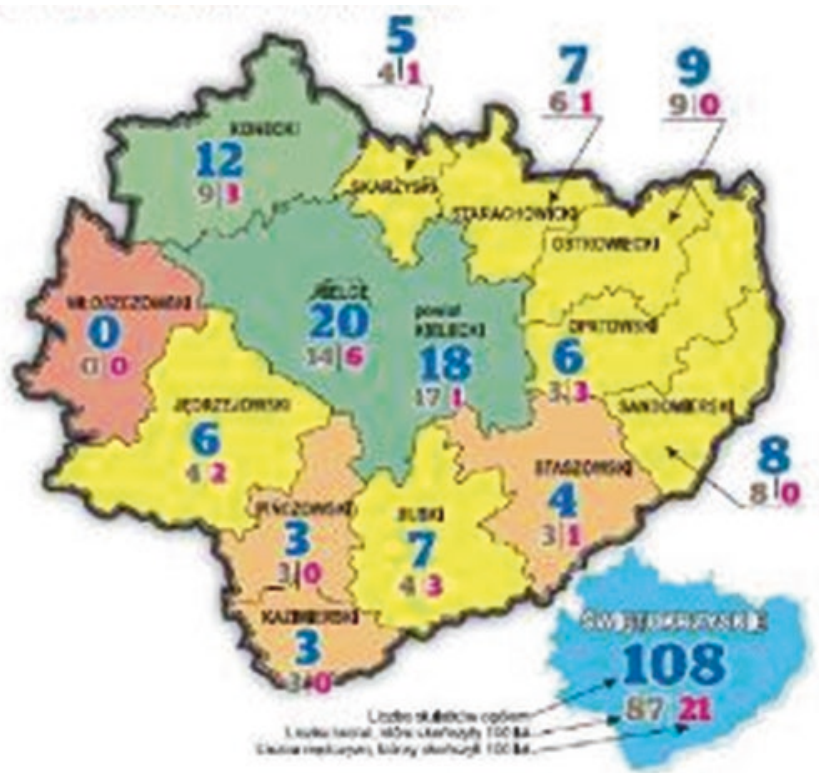

Fig. 11.16 Świętokrzyskie Voivodeship: number of centenarians by county, with Kielce and Konskie marked in green 


\subsubsection{Reported and Validated Repatriated Supercentenarians}

Our research identified 25 historical claims of supercentenarianship for persons born in what was once eastern Poland but was subsequently incorporated into the Soviet Union in 1945 and later became part of the independent countries of Lithuania, Belarus and Ukraine. Five were from Lithuania, fourteen were from Belarus, and six from Ukraine (see Table 11.4).

These claims are very difficult to research. First of all, the researcher must deal with various institutions in a different country, some of which are rather reluctant to cooperate, especially with a foreigner. Then, also, the claimants or their families often are not forthcoming - sometimes, no doubt, because they are aware that the claim is false. In fact, if the subject has not even truly reached age 100, there is a financial incentive to continue the charade, since Poland pays centenarians a high

Table 11.4 Repatriated historical supercentenarian cases

\begin{tabular}{|c|c|c|c|c|}
\hline & Date of birth & Date of death & Age (days) & Validation status \\
\hline \multicolumn{5}{|c|}{ Lithuania } \\
\hline Female & Mar. 29, 1892 & July 1, 2003 & $111(94)$ & Validated \\
\hline Female & May 22,1882 & Aug. 15, 1993 & $111(85)$ & False \\
\hline Male & June 7, 1898 & July 9, 2009 & $111(32)$ & Unvalidated \\
\hline Female & Jan 1,1896 & Feb. 3, 2006 & $110(33)$ & Validated \\
\hline Male & Feb. 2, 1906 & Feb. 4, 2016 & $110(2)$ & False \\
\hline \multicolumn{5}{|l|}{ Belarus } \\
\hline Female & Feb. 18, 1900 & Feb. 28, 2014 & $114(10)$ & False \\
\hline Female & May 1,1893 & Jan. 1, 2007 & $113(245)$ & Unvalidated \\
\hline Female & May 8, 1901 & Dec. 15,2014 & $113(221)$ & Unvalidated \\
\hline Female & Nov. 1,1887 & Jan. 30, 2000 & $112(142)$ & Unvalidated \\
\hline Female & Aug. 8, 1896 & Oct. 12,2008 & $112(64)$ & Unvalidated \\
\hline Female & May 17,1898 & July 13, 2010 & $112(57)$ & Unvalidated \\
\hline Female & Feb. 20,1886 & Mar. 29, 1998 & $112(37)$ & False \\
\hline Female & Oct. 11,1904 & Nov. 15,2015 & $111(35)$ & Unvalidated \\
\hline Female & Aug. 8, 1900 & Aug. 5, 2011 & $110(362)$ & Unvalidated \\
\hline Male & June 7, 1881 & Mar. 8, 1992 & $110(275)$ & Unvalidated \\
\hline Female & Mar. 13, 1900 & Dec. 8,2010 & $110(270)$ & Unvalidated \\
\hline Female & Sept. 24, 1904 & Nov. 19, 2014 & $110(56)$ & Unvalidated \\
\hline Female & Oct.15, 1896 & Nov.10, 2006 & $110(26)$ & Unvalidated \\
\hline Female & Apr. 10, 1906 & Apr. 18, 2016 & $110(8)$ & Unvalidated \\
\hline \multicolumn{5}{|c|}{ Ukraine } \\
\hline Male & Feb. 27, 1890 & Mar. 27, 2006 & $116(28)$ & False \\
\hline Male & Feb. 2, 1900 & Dec. 13,2013 & $113(314)$ & Disputed \\
\hline Female & Mar. 3, 1900 & Jan. 14, 2012 & $111(317)$ & Validated \\
\hline Male & July 19, 1894 & Dec. 6, 2005 & $111(140)$ & Validated \\
\hline Female & Aug. 23, 1870 & Sept. 24,1981 & $111(32)$ & Unvalidated \\
\hline Female & Mar. 7, 1897 & Mar. 5, 2008 & $110(364)$ & Unvalidated \\
\hline
\end{tabular}


allowance for care. By comparison, the families of the truly old often make the achievement public, since in Poland there is great respect for the aged. For instance, the family of Aleksandra Dranka celebrated each of her extreme-age birthdays with fanfare and media attention, and these were memorable events in the life of the local community.

Despite the difficulty, two cases from Lithuania and three from Ukraine were validated. One of the validated supercentenarians from Ukraine is the current oldest validated person living in Poland, Tekla Juniewicz. The other is Col. Jerzy Pajączkowski-Dydyński (1894-2005), who was born to Polish nobility, studied law in Lwów and Vienna, and was a veteran of World War I, the 1920 Polish-Russian War, and World War II. He left Poland together with the Polish government in Kuty on Sept. 17, 1939 and moved to the United Kingdom. Before his death in 2005 he may have been the oldest living male in Europe and the 4th oldest living male in the world.

A well-advertised case of a repatriate from present-day Ukraine is the case of Cpt. Józef Kowalski, who claimed to be the last surviving veteran of the PolishRussian War of 1920. Allegedly he was born in February 1900 and died in 2013 at the age of 113. Our research could not validate this claim because the birth registration of his village, Wicyń, was incomplete; on the contrary, it raised doubts about the truth of the claim since we found a registration record for the June 1900 birth of a sister.

One claim from Lithuania and one claim from Belarus were disproven. In the latter case all the evidence in Poland supported the woman's claim, and indeed the family was convinced of its authenticity and never sought to evade media attention. However, the early-life evidence obtained from present-day Belarus contradicted the Polish evidence. Apparently, when the woman and her husband came to Poland either during or shortly after World War II, both exaggerated their ages by 10 years.

\subsubsection{Validated Emigrant Supercentenarians}

In addition to the 11 validated supercentenarians who were born and last resided in Poland, there are 25 other validated supercentenarians who were born in Poland but last resided elsewhere. Ten of them last resided in the United States, nine in Germany, two in France and two in Israel, and one each in Switzerland and Canada. The total of 36 supercentenarians puts Poland in ninth place according to the GRG in the number of validated supercentenarians born in a country, behind the United States, Japan, the United Kingdom, Italy, France, Canada, Germany and Spain, and ahead of such countries as the Netherlands, Belgium, Sweden and Australia (Young et al. 2015). The complete list of these emigrant supercentenarians is given in Table 11.5.

The greatest number of emigrated supercentenarians were born in German Poland (15), followed by Russian Poland (7) and Austrian Poland (3). Most of the emigrants who were born in German Poland last resided in Germany, presumably 
11 Centenarians, Semi-supercentenarians and the Emergence of Supercentenarians...

Table 11.5 Validated emigrant supercentenarians born in present-day Poland (as of Sept. 2017)

\begin{tabular}{|c|c|c|c|c|c|c|c|}
\hline Name & $\begin{array}{l}\text { Birth } \\
\text { date }\end{array}$ & $\begin{array}{l}\text { Death } \\
\text { date }\end{array}$ & Years & Days & $\begin{array}{l}\text { Country } \\
\text { of birth }\end{array}$ & $\begin{array}{l}\text { Modern } \\
\text { voivodeship }\end{array}$ & Last residence \\
\hline 1 Augusta Holtz & $\begin{array}{l}\text { Aug. } \\
3, \\
1871\end{array}$ & $\begin{array}{l}\text { Oct. } \\
21, \\
1986\end{array}$ & 115 & 79 & $\begin{array}{l}\text { German } \\
\text { Empire }\end{array}$ & $\begin{array}{l}\text { Greater } \\
\text { Poland }\end{array}$ & USA (Missouri) \\
\hline $\begin{array}{l}2 \quad \text { Mary } \\
\text { Drymalski }\end{array}$ & $\begin{array}{l}\text { July } \\
24, \\
1883\end{array}$ & $\begin{array}{l}\text { Dec. 1, } \\
1993\end{array}$ & 110 & 130 & $\begin{array}{l}\text { German } \\
\text { Empire }\end{array}$ & $\begin{array}{l}\text { Kuyavia- } \\
\text { Pomerania }\end{array}$ & USA (Illinois) \\
\hline $\begin{array}{l}3 \text { Franziska } \\
\text { Umrath }\end{array}$ & $\begin{array}{l}\text { Sept. } \\
5, \\
1885\end{array}$ & $\begin{array}{l}\text { Feb. } \\
18, \\
1996\end{array}$ & 110 & 166 & $\begin{array}{l}\text { German } \\
\text { Empire }\end{array}$ & Pomerania & Germany \\
\hline 4 Pauline Spyra & $\begin{array}{l}\text { Apr. } \\
24, \\
1886 \\
\end{array}$ & $\begin{array}{l}\text { Jan. } \\
11, \\
1997 \\
\end{array}$ & 110 & 262 & $\begin{array}{l}\text { German } \\
\text { Empire }\end{array}$ & Silesia & Germany \\
\hline 5 Meta Berndt & $\begin{array}{l}\text { Nov. } \\
9, \\
1889 \\
\end{array}$ & $\begin{array}{l}\text { Dec. } \\
28, \\
2001\end{array}$ & 112 & 49 & $\begin{array}{l}\text { German } \\
\text { Empire }\end{array}$ & Pomerania & Germany \\
\hline $\begin{array}{l}6 \text { Theresa } \\
\text { Bernstein- } \\
\text { Meyerowitz }\end{array}$ & $\begin{array}{l}\text { Mar. } \\
1, \\
1890\end{array}$ & $\begin{array}{l}\text { Feb. } \\
13, \\
2002 \\
\end{array}$ & 111 & 349 & $\begin{array}{l}\text { Austria- } \\
\text { Hungary }\end{array}$ & Lesser Poland & $\begin{array}{l}\text { USA (New } \\
\text { York) }\end{array}$ \\
\hline $\begin{array}{l}7 \text { Joseph } \\
\text { Rabenda }\end{array}$ & $\begin{array}{l}\text { Jan. } \\
10, \\
1892\end{array}$ & $\begin{array}{l}\text { Feb. } \\
19, \\
2003\end{array}$ & 111 & 40 & $\begin{array}{l}\text { Russian } \\
\text { Empire }\end{array}$ & $\begin{array}{l}\text { Greater } \\
\text { Poland }\end{array}$ & France \\
\hline $\begin{array}{l}8 \text { Frieda } \\
\text { Borchert }\end{array}$ & $\begin{array}{l}\text { Jan. 5, } \\
1897\end{array}$ & $\begin{array}{l}\text { June } \\
22, \\
2008 \\
\end{array}$ & 111 & 169 & $\begin{array}{l}\text { German } \\
\text { Empire }\end{array}$ & Lubuskie & Germany \\
\hline 9 Rosa Rein & $\begin{array}{l}\text { Mar. } \\
24, \\
1897\end{array}$ & $\begin{array}{l}\text { Feb. } \\
14, \\
2010\end{array}$ & 112 & 327 & $\begin{array}{l}\text { German } \\
\text { Empire }\end{array}$ & Silesia & Switzerland \\
\hline $\begin{array}{l}10 \text { Dr. Maria } \\
\text { Pogonowska }\end{array}$ & $\begin{array}{l}\text { Oct. } \\
30, \\
1897\end{array}$ & $\begin{array}{l}\text { July } \\
15, \\
2009\end{array}$ & 111 & 258 & $\begin{array}{l}\text { Russian } \\
\text { Empire }\end{array}$ & Masovia & Israel \\
\hline 11 Fannie Buten & $\begin{array}{l}\text { Apr. } \\
13, \\
1899\end{array}$ & $\begin{array}{l}\text { Sept. } \\
24, \\
2010\end{array}$ & 111 & 164 & $\begin{array}{l}\text { Austria- } \\
\text { Hungary }\end{array}$ & Subcarpathia & $\begin{array}{l}\text { USA } \\
\text { (Pennsylvania) }\end{array}$ \\
\hline $\begin{array}{l}12 \text { Maria } \\
\text { Gerstman }\end{array}$ & $\begin{array}{l}\text { Oct. } \\
30, \\
1900\end{array}$ & $\begin{array}{l}\text { Dec. } 7, \\
2012\end{array}$ & 112 & 38 & $\begin{array}{l}\text { Russian } \\
\text { Empire }\end{array}$ & Podlaskic & $\begin{array}{l}\text { USA (New } \\
\text { York) }\end{array}$ \\
\hline $\begin{array}{l}13 \text { Anna } \\
\text { Lewicki }\end{array}$ & $\begin{array}{l}\text { Dec. } \\
6, \\
1900 \\
\end{array}$ & $\begin{array}{l}\text { Jan. 3, } \\
2010\end{array}$ & 111 & 28 & $\begin{array}{l}\text { Austria- } \\
\text { Hungary }\end{array}$ & Subcarpathia & $\begin{array}{l}\text { USA (New } \\
\text { York) }\end{array}$ \\
\hline 14 Rose Berman & $\begin{array}{l}\text { Feb. } \\
28, \\
1901\end{array}$ & $\begin{array}{l}\text { Jan. } \\
12, \\
2012\end{array}$ & 110 & 318 & $\begin{array}{l}\text { Russian } \\
\text { Empire }\end{array}$ & unknown & USA (Florida) \\
\hline $\begin{array}{l}15 \text { Thea } \\
\text { Breckerbaum }\end{array}$ & $\begin{array}{l}\text { Oct. } \\
6, \\
1902\end{array}$ & $\begin{array}{l}\text { Nov. } \\
25, \\
2012\end{array}$ & 110 & 50 & $\begin{array}{l}\text { German } \\
\text { Empire }\end{array}$ & $\begin{array}{l}\text { Greater } \\
\text { Poland }\end{array}$ & Germany \\
\hline
\end{tabular}


Table 11.5 (continued)

\begin{tabular}{|c|c|c|c|c|c|c|c|}
\hline Name & $\begin{array}{l}\text { Birth } \\
\text { date }\end{array}$ & $\begin{array}{l}\text { Death } \\
\text { date }\end{array}$ & Years & Days & $\begin{array}{l}\text { Country } \\
\text { of birth }\end{array}$ & $\begin{array}{l}\text { Modern } \\
\text { voivodeship }\end{array}$ & Last residence \\
\hline 16 Maria Jantke & $\begin{array}{l}\text { Oct. } \\
18, \\
1902\end{array}$ & $\begin{array}{l}\text { Mar. 9, } \\
2013\end{array}$ & 110 & 142 & $\begin{array}{l}\text { German } \\
\text { Empire }\end{array}$ & Pomerania & Germany \\
\hline $\begin{array}{l}17 \text { Anna } \\
\text { Palarowska (s. } \\
\text { Bernadetta }\end{array}$ & $\begin{array}{l}\text { Oct. } \\
22 \\
1902\end{array}$ & $\begin{array}{l}\text { Nov. 2, } \\
2013\end{array}$ & 111 & 11 & $\begin{array}{l}\text { German } \\
\text { Empire }\end{array}$ & $\begin{array}{l}\text { Warmia- } \\
\text { Masuria }\end{array}$ & France \\
\hline $\begin{array}{l}18 \text { Johanna } \\
\text { Klink }\end{array}$ & $\begin{array}{l}\text { Jan. } \\
17, \\
1902\end{array}$ & $\begin{array}{l}\text { Feb. } \\
20 \\
2015\end{array}$ & 112 & 34 & $\begin{array}{l}\text { German } \\
\text { Empire }\end{array}$ & Silesia & Germany \\
\hline $\begin{array}{l}19 \text { Dr. } \\
\text { Alexander Imich }\end{array}$ & $\begin{array}{l}\text { Feb. } \\
4, \\
1903\end{array}$ & $\begin{array}{l}\text { June } 8 \text {, } \\
2014\end{array}$ & 111 & 124 & $\begin{array}{l}\text { Russian } \\
\text { Empire }\end{array}$ & Silesia & $\begin{array}{l}\text { USA (New } \\
\text { York) }\end{array}$ \\
\hline $\begin{array}{l}20 \text { Margarete } \\
\text { Ottmann }\end{array}$ & $\begin{array}{l}\text { Feb. } \\
23, \\
1903\end{array}$ & $\begin{array}{l}\text { Aug. } \\
17, \\
2014\end{array}$ & 111 & 175 & $\begin{array}{l}\text { German } \\
\text { Empire }\end{array}$ & Opole & Germany \\
\hline $\begin{array}{l}21 \text { Eva } \\
\text { Grafunder }\end{array}$ & $\begin{array}{l}\text { June } \\
17, \\
1903\end{array}$ & $\begin{array}{l}\text { July } \\
14, \\
2013\end{array}$ & 110 & 27 & $\begin{array}{l}\text { German } \\
\text { Empire }\end{array}$ & $\begin{array}{l}\text { Warmia- } \\
\text { Masuria }\end{array}$ & $\begin{array}{l}\text { Canada (British } \\
\text { Columbia) }\end{array}$ \\
\hline 22 Israel Kristal & $\begin{array}{l}\text { Sept. } \\
15 \text {, } \\
1903\end{array}$ & $\begin{array}{l}\text { Aug. } \\
11 \text {, } \\
2017\end{array}$ & 113 & 330 & $\begin{array}{l}\text { Russian } \\
\text { Empire }\end{array}$ & Lodz & Israel \\
\hline 23 Hedy Wegier & $\begin{array}{l}\text { Oct. } \\
25, \\
1903\end{array}$ & $\begin{array}{l}\text { May } \\
12, \\
2015\end{array}$ & 111 & 199 & $\begin{array}{l}\text { German } \\
\text { Empire }\end{array}$ & Silesia & $\begin{array}{l}\text { USA (New } \\
\text { York) }\end{array}$ \\
\hline $\begin{array}{l}24 \text { Elisabeth } \\
\text { Franke }\end{array}$ & $\begin{array}{l}\text { Nov. } \\
10, \\
1903\end{array}$ & $\begin{array}{l}\text { Aug. } \\
11 \text {, } \\
2014\end{array}$ & 110 & 274 & $\begin{array}{l}\text { German } \\
\text { Empire }\end{array}$ & Lower Silesia & Germany \\
\hline 25 Ida Tallin & $\begin{array}{l}\text { Sept. } \\
25, \\
1905\end{array}$ & $\begin{array}{l}\text { Aug. } \\
5, \\
2016\end{array}$ & 110 & 315 & $\begin{array}{l}\text { Russian } \\
\text { Empire }\end{array}$ & Podlaskie & USA (Florida) \\
\hline
\end{tabular}

Subsequent research proved that Rose Berman was actually born in present-day Ukraine (Apr. 2018)

reflecting the post-war expulsion of Germans from Silesia and Pomerania. Figure 11.17 shows the distribution of the 25 supercentenarians by voivodeship of birth.

The oldest supercentenarian born in present-day Poland is Augusta Holtz (1871-1986), who, with a validated age of 115 years 79 days was the world record holder, likely the first person to have reached the age of 115 (see Chap. 22), until she was surpassed by Jeanne Calment in 1990. Two of Poland's emigrant supercentenarians were recognized in the Guinness Book of World Records as the world's oldest living male. One is Israel Kristal, who last resided in Israel (see Chap. 20). The other is Dr. Alexander Imich, quite a remarkable man, proven to have been the last surviving veteran of the aforementioned 1920 Polish-Soviet War. Dr. Imich devoted his life to the scientific study of parapsychology and paranormal 


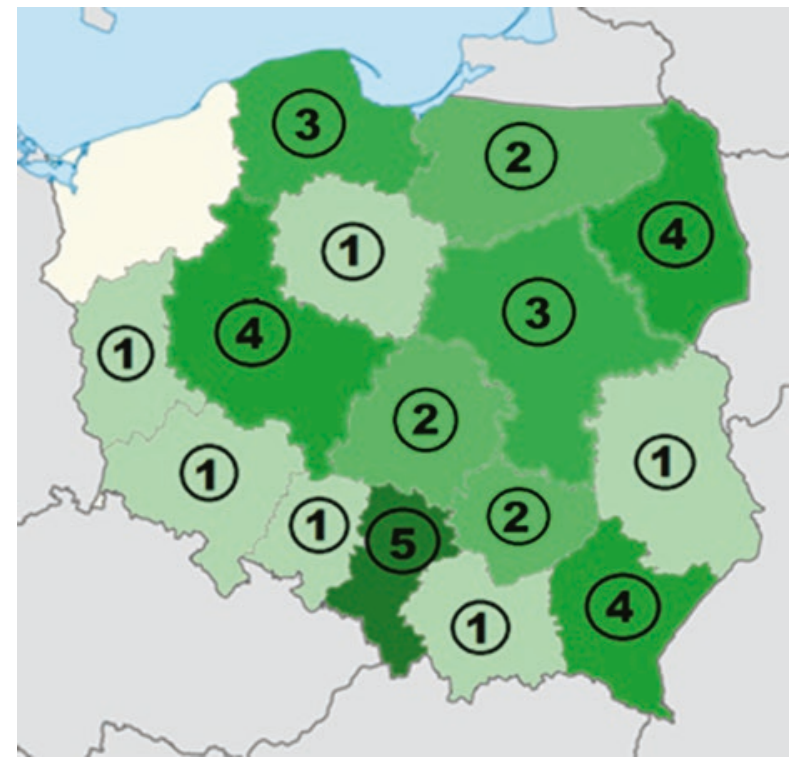

Fig. 11.17 Number of validated supercentenarians born in present-day Poland by modern Voivodeship of birth

phenomena, and continued his studies until a very old age, in fact publishing a book on these subjects when he was in his 90s. He survived imprisonment in a Soviet labor camp during World War II and came afterwards with his wife to New York. The author was still in an e-mail correspondence with Dr. Imich in the year of Dr. Imich's death.

\subsection{Conclusion}

Official statistics on Polish longevity, while not highly accurate, may be useful for making comparisons or observing trends, particularly if restricted to "Poland A". Our primary focus since we began in November 2012 is to validate allegations of extreme age. With respect to supercentenarians, we were able to validate the status of 14 people, all women, who last resided in Poland. We also observed the interesting phenomenon that about twice as many validated supercentenarians were born in Poland and last resided elsewhere.

We are continuing the search for true supercentenarians in Poland and looking forward to a more comprehensive study of Polish longevity.

Acknowledgements I thank Bert Kestenbaum for his many helpful suggestions on an early draft of this manuscript. 
I wish to thank my mentors, Mr. Robert D. Young, M.A., M.A., of Atlanta, and Dr. Maria Kempa, Ph.D., of the Medical University of Silesia, for encouraging me, for their selfless support, priceless advice and unshakeable belief that extreme longevity tracking and supercentenarian study in Poland would become reality.

I would like to express my gratitude for the invaluable commitment of Messrs. Przemysław Kuty, Łukasz Szołdra and Michał Sędziak, my Polish colleagues who share my passion for longevity research; and a thank you to Georg Fürholzer of Austria and Victor Bjoerk of Sweden for giving me the joy of visiting Emma Morano, the last survivor of the 1800s.

Special thanks to the longevity researchers associated with the Max Planck Institute for Demographic Research and the team of GRG correspondents for their friendship and eagerness to share their experience.

Very special thanks to the families of supercentenarians for their cordiality, in particular to Mrs. Krystyna Dziedzic and Mr. Piotr Dziedzic, the daughter and the grandson of Mrs. Aleksandra Dranka (1903-2014), respectively; to Janina Juniewicz-Stachowska, Anna Stachowska and Adam Stachowski, the daughter and grandchildren of Mrs. Tekla Juniewicz (1906-present); to Leonarda Skorulska and Beata Horodylowska, the daughter and great-granddaughter of Mrs. Jadwiga Zolotucho (1892-2003); to Joanna Milczarek, great-great-granddaughter of Mrs. Rozalia Milczarek (1869-1981); to Danuta Kieza, granddaughter of Mrs. Marianna Smolarczyk (1897-2007); to Marta Zawadzka, daughter of Mrs. Czesława Łasiewicz (1907-present); to Prof. Zbigniew Semadeni, son-in-law of Mrs. Wanda Wierzchleyska (1900-2012); and to Janina \& Józef Cudny and Ewa Dados of Radio Lublin and Karen Bogen of New York, a relative of Dr. Alexander Imich.

This chapter is dedicated to the memory of Mrs. Jadwiga Szubartowicz (1905-2017), supercentenarian and Doyenne of Poland, for her hospitality, friendship and inspiration for life; and to the memory of Ms. Stefania Zacharska (1906-2016) of Tarnowskie Góry, the semi-supercentenarian from my town of birth, whose life story inspired me to study the phenomenon of human longevity.

\section{References}

Czech Social Security Bureau (Česká správa sociálního zabezpečení) (http://www.cssz.cz)

Gerontology Research Group. University of California Los Angeles (1990-2017). GRG Table A, GRG pending cases, World's supercentenarian ranking list. www.grg.org

Gerontology Research Group. University of California Los Angeles (1990-2017). Database of semisupercentenarians in Germany. In T. Breining, \& S. Jamin (Eds) www.grg.org

Jeune, B., \& Vaupel, J. W. (1999). Validation of exceptional longevity (Monograph on population aging 6). Odense: Odense University Press.

Kannisto, V. (1994). Development of oldest-old mortality, 1950-1990: Evidence from 28 developed countries. Odense: Odense University Press.

Lynch, K. (2014). Dr. Alexander Imich confirmed as new world's oldest man at 111. https://www. guinnessworldrecords.com/

Lynch, K. (2016). Guinness World Records announces Holocaust survivor Israel Kristal as world's oldest living man. https://www.guinnessworldrecords.com/

Maier, H., \& Scholz, R. (2010) Age validation of persons aged 105 and above in Germany. In H. Maier, J. Gampe, B. Jeune, J.-M. Robine, \& J. W. Vaupel (Eds.) Supercentenarians (pp. 173-191). Berlin: Springer Verlag.

Mossakowska, M., \& Jaczewska, B. (2006). Ile lat ma polski stulatek? International Institute of Molecular and Cellular Biology in Warsaw.

Mossakowska, M., \& Szybalska, A. (2008). Stulatkowie w świetle spisu powszechnego, International Institute of Molecular and Cellular Biology in Warsaw.

Najstarsi Polacy. (2015-2017). Oldest people in Poland (www.najstarsipolacy.pl) 
Poulain, M. (2010). On the age validation of supercentenarians. In H. Maier, J. Gampe, B. Jeune, J.-M. Robine, \& J. W. Vaupel (Eds.), Supercentenarians (pp. 3-30). Berlin: Springer Verlag. Skytthe, A., Hervonen, A., Ruisdael, C., \& Jeune, B. (2010). Supercentenarians in the Nordic countries. In H. Maier, J. Gampe, B. Jeune, J.-M. Robine, \& J. W. Vaupel (Eds.), Supercentenarians (pp. 203-216). Berlin: Springer Verlag.

Szukalski, P. (2002). Stulatkowie - szkic demograficzny. Gerontologia Polska, 10(2), 62-67.

Thoms, W. J. (1873). Human longevity. Its facts and fictions. London: John Murray.

Young, R., Epstein, L., \& Coles, L. S. (2009a). Supercentenarian counts by nation of birth. Rejuvenation Research, 12(5), 375-377.

Young, R., Epstein, L., \& Coles, L. S. (2009b). Global mortality rates beyond age 110. Rejuvenation Research, 12(2), 159-160.

Young, R., Muir, M., \& Adams, J. (2015). Validated worldwide supercentenarians, living and recently deceased: February 2015. Rejuvenation Research, 18(1), 96-100.

Open Access This chapter is licensed under the terms of the Creative Commons Attribution 4.0 International License (http://creativecommons.org/licenses/by/4.0/), which permits use, sharing, adaptation, distribution and reproduction in any medium or format, as long as you give appropriate credit to the original author(s) and the source, provide a link to the Creative Commons license and indicate if changes were made.

The images or other third party material in this chapter are included in the chapter's Creative Commons license, unless indicated otherwise in a credit line to the material. If material is not included in the chapter's Creative Commons license and your intended use is not permitted by statutory regulation or exceeds the permitted use, you will need to obtain permission directly from the copyright holder. 